\title{
Characterisation of novel missense mutations in the GH receptor gene causing severe growth retardation
}

\author{
B Enberg, H Luthman, K Segnestam ${ }^{1}$, E M Ritzén ${ }^{2}$, M Sundström ${ }^{3}$ and G Norstedt \\ Department of Molecular Medicine, Karolinska Hospital S-171 76 Stockholm, Sweden, ${ }^{1}$ Mälarsjukhuset, Eskilstuna, Sweden, \\ ${ }^{2}$ Department of Women and Child Health, Karolinska Hospital, S-171 76 Stockholm, Sweden and ${ }^{3}$ Pharmacia and Upjohn AB, Stockholm, Sweden \\ (Correspondence should be addressed to Gunnar Norstedt, Department of Molecular Medicine, Karolinska Institutet, Karolinska Hospital 17176 , \\ Stockholm, Sweden; Email: gunnar.norstedt@molmed.ki.se)
}

\begin{abstract}
Two Swedish brothers, 2.5 and 4 years of age, were found to fulfil all the clinical and laboratory characteristics of Laron's syndrome. They were shown to have unique missense mutations in the GH receptor gene. Both of their parents were of normal height, but they both separately carried one of the identified gene alterations. A molecular model of the first receptor alteration suggests that a collapse in three-dimensional receptor structure most likely contributed to the GH insensitivity in these patients.
\end{abstract}

European Journal of Endocrinology 143 71-76

\section{Introduction}

Laron's syndrome (LS) is a rare genetic disease causing severe dwarfism (1). Patients frequently carry alterations in the growth hormone $(\mathrm{GH})$ receptor gene (2). The mature $\mathrm{GH}$ receptor is a single membrane-spanning protein of 620 amino acids (3). The most related molecule known is the prolactin receptor (4). Both of these receptors belong to the cytokine receptor superfamily (5). A soluble form of the receptor, GH-binding protein $(\mathrm{GH}-\mathrm{BP})$, corresponding to the extracellular part of the GH receptor has been identified in plasma (6). The absence of GH-BP denoting a defect in the extracellular domain of the $\mathrm{GH}$ receptor is found in most patients with LS (7-9). Upon ligand binding to the extracellular part, the $\mathrm{GH}$ receptor has been shown to dimerise, thereby forming a receptor to ligand 2:1 complex. Ligand-induced receptor signalling has been shown to involve multiple events, e.g. receptor tyrosine phosphorylation, activation of Stat-proteins, Janus and MAP kinases (10).

$\mathrm{LS}$ is characterised by resistance to $\mathrm{GH}$ and low serum levels of insulin-like growth factor-I (IGF-I) (11), an important mediator of $\mathrm{GH}$ action produced in multiple GH-responsive cell types (12). Patients have predominantly been found in the Mediterranean region and in two isolated provinces in South America (13). More than 25 different missense, nonsense, frameshift and splice mutations in the $\mathrm{GH}$ receptor gene have so far been identified in LS patients (14). During the last decade a successful therapeutic treatment of LS patients has been developed using recombinant IGF-I (15). Here we have analysed the $\mathrm{GH}$ receptor nucleotide sequence of the first two cases of LS that have been identified in native Swedes.

\section{Subjects and methods}

\section{Case 1}

This was the first child of unrelated parents, born after 38 weeks of gestation. The parents were of Swedish origin with average heights (180.2 and $167.5 \mathrm{~cm})$. Birth weight was $3430 \mathrm{~g}$. Birth length was reported to be $48 \mathrm{~cm}$. His growth rate was already subnormal at 3 months, and when first presented for work-up of short stature at age 1.7 years his height was at -4.5 SDS. He was then noted to have a small penis, frontal bossing, low nasal bridge, moderate obesity and normal psychomotor development (Fig. 1). Results from laboratory studies before treatment are given in Table 1. During arginine tolerance tests, GH levels increased from a baseline of $54 \mu \mathrm{g} / \mathrm{l}$ to a maximum of $94 \mu \mathrm{g} / \mathrm{l}$, and spontaneous $\mathrm{GH}$ levels in blood during $12 \mathrm{~h}$ of sampling every $30 \mathrm{~min}$ revealed levels between 4.6 and $102 \mu \mathrm{g} / \mathrm{l}$ (mean $37.1 \mu \mathrm{g} / \mathrm{l})$. As a further diagnostic test for $\mathrm{GH}$ sensitivity, GH (Genotropin; Pharmacia \& Upjohn, Stockholm, Sweden) was administered for 10 days at a dose of $0.1 \mu \mathrm{g} / \mathrm{kg}$ body weight (BW) per day, followed by $0.3 \mu \mathrm{g} / \mathrm{kg}$ for 3 months. No significant increase in IGF-I levels in blood was noted during the GH treatment. During that time, there was no measurable growth at all. At the age of 5 years, IGF-I (Igef; Pharmacia \& Upjohn) treatment could be started in increasing doses from 40 to $120 \mu \mathrm{g} / \mathrm{kg} \mathrm{BW}$ twice daily. This continued for 


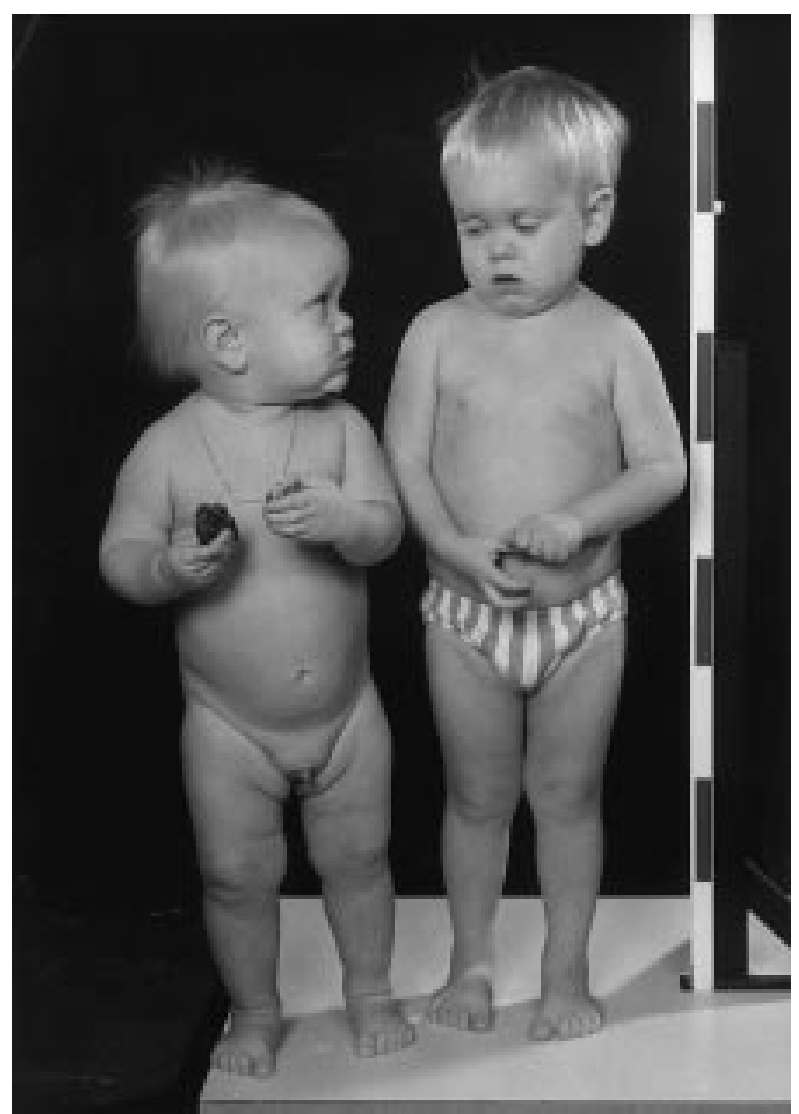

Figure 1 Photograph of the two boys with $\mathrm{GH}$ insensitivity at ages 4 and 2.5 years respectively. Note frontal bossing, small midface, moderate obesity and small genitalia.

4 years, resulting in an increase in height from -6 to -3.8 SDS. During an interruption in IGF-I treatment for 4 months at the age of 9.2 years, there was no demonstrable growth. Hypertrophy of the tonsils caused sleep apnoea and difficulties in swallowing solid food, and tonsillectomy was therefore performed at 8 years of age. Moderate tachycardia (100-120) was noted at many visits. Echocardiography remained normal after 3 years of therapy. His growth chart is shown in Fig. 2. There were no clinical or laboratory signs of hypoglycaemia.

\section{Case 2}

This was the 2-years younger brother of case 1 . He was born after 39 weeks of gestation, with a birth weight of
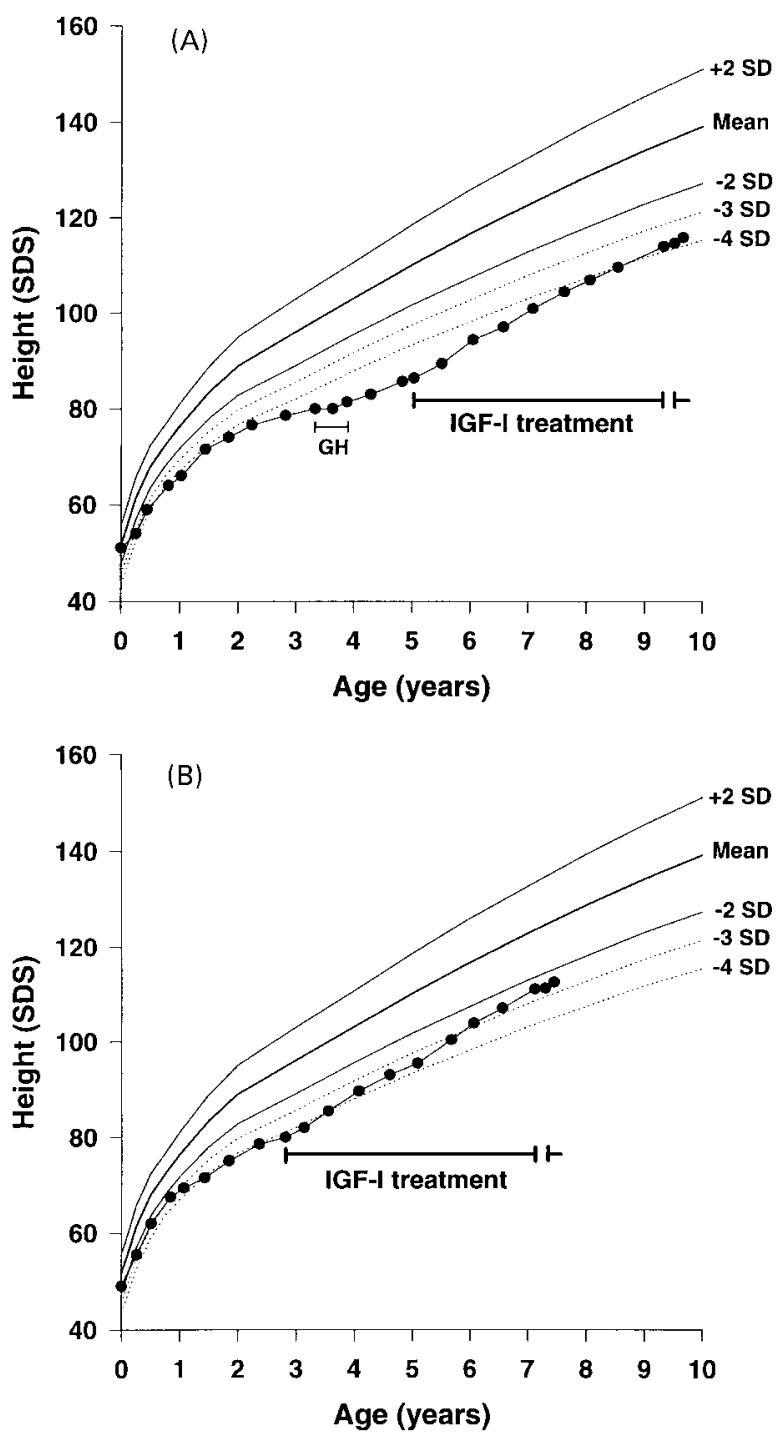

Figure 2 Growth charts of the two brothers (A and B) with GH insensitivity, illustrating the growth before and during IGF-I therapy. The older brother $(\mathrm{A})$ was treated with $\mathrm{GH}$ for a 5-month period, without any measurable growth at all. This was also the case during a 5-month period of interrupted IGF-I therapy.

$3445 \mathrm{~g}$ and length $49 \mathrm{~cm}$. There were no neonatal complications. His height fell from -1 to -3 SDS from birth to 3 months, and further to -4 SDS by 18 months of age. At that time his brother had been diagnosed as

Table 1 Laboratory findings in the two brothers with GH insensitivity, at start of Igef treatment.

\begin{tabular}{lccccccccccc}
\hline & $\begin{array}{c}\text { Age } \\
(\text { years })\end{array}$ & $\begin{array}{c}\text { Bone } \\
\text { age } \\
(\text { years })\end{array}$ & $\begin{array}{c}\text { Height } \\
(\mathrm{cm})\end{array}$ & $\begin{array}{c}\text { Weight } \\
(\mathrm{kg})\end{array}$ & $\begin{array}{c}\text { GH } \\
(\mu \mathrm{g} / \mathrm{l})\end{array}$ & $\begin{array}{c}\mathrm{IGF}-\mathrm{I} \\
(\mu \mathrm{g} / \mathrm{l})\end{array}$ & $\begin{array}{c}\text { BP-I } \\
(\mu \mathrm{g} / \mathrm{l})\end{array}$ & $\begin{array}{c}\mathbf{I G F}-\mathrm{II} \\
(\mu \mathrm{g} / \mathrm{l})\end{array}$ & $\begin{array}{c}\text { BP-3 } \\
(\mu \mathrm{g} / \mathrm{l})\end{array}$ & $\begin{array}{c}\text { GH-BP } \\
(\mathrm{pmol} / \mathrm{l})\end{array}$ & $\begin{array}{l}\text { Insulin } \\
(\mathrm{mU} / \mathrm{l})\end{array}$ \\
\hline Case 1 & 5.0 & 3.2 & 86 & 11.9 & 180 & $<10$ & 247 & 81 & 477 & $<15.6$ & 10 \\
Case 2 & 2.8 & & 74 & 11.2 & 35 & $<20$ & 333 & 80 & 486 & - & 9 \\
\hline
\end{tabular}

$\mathrm{BP}$, binding protein. 
GH insensitive, and since their phenotypes were almost identical (Fig. 1), only a limited work-up was done. GH levels were between 2.1 and $30 \mu \mathrm{g} / \mathrm{l}$ during blood sampling every $30 \mathrm{~min}$ for $6 \mathrm{~h}$ (mean $12.6 \mu \mathrm{g} / \mathrm{l}$ ). A diagnostic test treatment with $\mathrm{GH}$, administered at a dose of $0.1 \mathrm{U} / \mathrm{kg}$ per day for 10 days, did not raise IGF-I levels above $10 \mu \mathrm{g} / \mathrm{l}$. Treatment with Igef was started at 3 years of age, with a gradual increase in the dose from 40 to $120 \mu \mathrm{g} / \mathrm{kg}$ BW twice daily. At the start of treatment with Igef, there was one clinical episode of hypoglycaemia, but not later during the 4 years of treatment. Similar to his brother, he was tonsillectomised after 3 years of treatment. When IGF-I therapy was discontinued for 4 months at 7 years of age, there was no measurable growth.

\section{Isolation of genomic DNA from nucleated blood cells}

Heparinised blood samples $(5 \mathrm{ml})$ were added to $25 \mathrm{ml}$ lysis buffer $\left(1 \mathrm{mM} \mathrm{NH} 4 \mathrm{HCO}_{3}, 114 \mathrm{mM} \mathrm{NH}_{4} \mathrm{Cl}\right)$ and centrifuged at $4000 \mathrm{~g}$ for $10 \mathrm{~min}$ at $20^{\circ} \mathrm{C}$. Pellets were resuspended in $1 \mathrm{ml} \mathrm{NP}-40$ buffer $(10 \mathrm{mM}$ Tris- $\mathrm{HCl}$, $\mathrm{pH} 7.5,3 \mathrm{mM} \mathrm{MgCl} 2,10 \mathrm{mM} \mathrm{NaCl}, 0.5 \% \mathrm{NP}-40, \mathrm{v} / \mathrm{v})$ incubated for $5 \mathrm{~min}$ and centrifuged as above. Pellets were resuspended in $0.75 \mathrm{ml}$ ProtK buffer $(0.5 \%$ SDS, $120 \mathrm{mM}$ EDTA, $75 \mathrm{mM} \mathrm{NaCl}, 0.6 \mathrm{mg} / \mathrm{ml}$ proteinase K) and incubated at $45^{\circ} \mathrm{C}$ for $2 \mathrm{~h}$. After repeated phenol/ chloroform and chloroform extractions DNA was recovered by ethanol precipitation. Pellets were dissolved in Tris-EDTA and nucleic acid content was determined by spectrophotometric analysis.

\section{Preparation and sequencing of exon-specific GH receptor DNA templates}

Computer-aided design (Oligo 4.05; National Biosciences, Plymouth, MN, USA) of PCR primers directed towards exon-flanking sequences in the human $\mathrm{GH}$ receptor gene allowed amplification of exons 2, 4, 5, 6 and 7. An Expedite nucleic acid synthesis system (Millipore Corporation and Cybergene, Huddinge, Sweden) was used for all primers synthesised. Sequences of primers used for exon 7 were TGGCATTGAGTTGTTGA, TGATTTGGACAACACACTA, TATTGACAAAAGCCAGGTT and TTGACAAAAGCCAGGTTAG.

Reactions containing 10 ng genomic DNA (omitted in negative controls), $2.5 \mathrm{mM} \mathrm{MgCl}_{2}, 0.2 \mu \mathrm{M}$ dNTP, $0.5 \mu \mathrm{M}$ of each primer and $0.5 \mathrm{U}$ Taq polymerase in $25 \mu \mathrm{l}$ of $1 \times$ Taq polymerase buffer (Promega, Madison, WI, USA) were run in a Gene Amp 2400 thermal cycler (Perkin-Elmer, Norwalk, CT, USA). All DNA amplifications included 40 cycles with denaturation at $96^{\circ} \mathrm{C}$ for $15 \mathrm{~s}$, annealing at $51-54^{\circ} \mathrm{C}$ (exon-dependent temperature) for $5 \mathrm{~s}$, and extension at $72{ }^{\circ} \mathrm{C}$ for $10 \mathrm{~s}$. Aliquots of terminated reactions analysed on $1 \%$ agarose gels rendered single bands of expected size. One microlitre of primary reactions was used in $50 \mu \mathrm{l}$ nested PCR reactions with one primer biotinylated (conditions as described above except that primer concentrations were reduced to $0.2 \mu \mathrm{M}$ and Taq polymerase content increased to $1 \mathrm{U})$. In the nested PCR negative controls containing $1 \mu \mathrm{l}$ reaction mix from corresponding negative controls in primary amplification, no visible products were yielded upon agarose gel analysis. Exonspecific biotinylated PCR products in $46 \mu \mathrm{l}$ of secondary nested PCR reactions were trapped on streptavidincoated magnetic beads (Dynabeads, Dynal A/S, Oslo, Norway). Following binding and washing, DNA strands were separated as recommended by the magnetic bead supplier. Flourochrome (Pharmacia Biotech, Uppsala, Sweden)-labelled sequencing primers were annealed either to solid phases or to neutralised soluble phases and sequencing reactions were run at $50{ }^{\circ} \mathrm{C}$ using a cycle sequencing kit (Pharmacia Biotech). Separation and detection of sequencing products were carried out on an automated DNA sequencer. Templates carrying missense mutations were sequenced in both directions.

\section{Structure determination}

A structural gene encoding the extracellular domain of the human (h) $\mathrm{GH}$ receptor was amplified from commercially available adult liver cDNA (Clontech, Palo Alto, CA, USA) using PCR. The sequence amplified encodes the first 237 residues of the hGH-binding protein. Expression and purification of the receptor construct have previously been described in detail by Sundström et al. (16). hGH was obtained from Pharmacia \& Upjohn AB, Sweden. The 1:2 complex of hGH and hGH-binding protein was purified and crystallised, and the structure determined as previously described (16). The structure of the 1:2 complex refined to $2.5 \AA$ resolution served as a template for the structural interpretation of the consequences of the Tyr208 to Cys mutation of the receptor extracellular domain.

\section{Results}

Clinically, these two children presented a markedly reduced growth rate with an early onset (Fig. 2). The parents were of normal stature. A summary of laboratory findings in the two brothers can be found in Table 1. Serum GH concentrations were high in both patients while serum levels of IGF-I were below the detection limit of the assay. Together with the inability of exogenous $\mathrm{GH}$ administration to influence either serum IGF-I or growth, a severe form of GH insensitivity was diagnosed. These data and the finding of unmeasurable levels of the soluble form of the GH-BP, suggested a Laron-type short stature.

Southern blotting using two human cDNA probes spanning the entire coding region of the $\mathrm{GH}$ receptor 
(A)
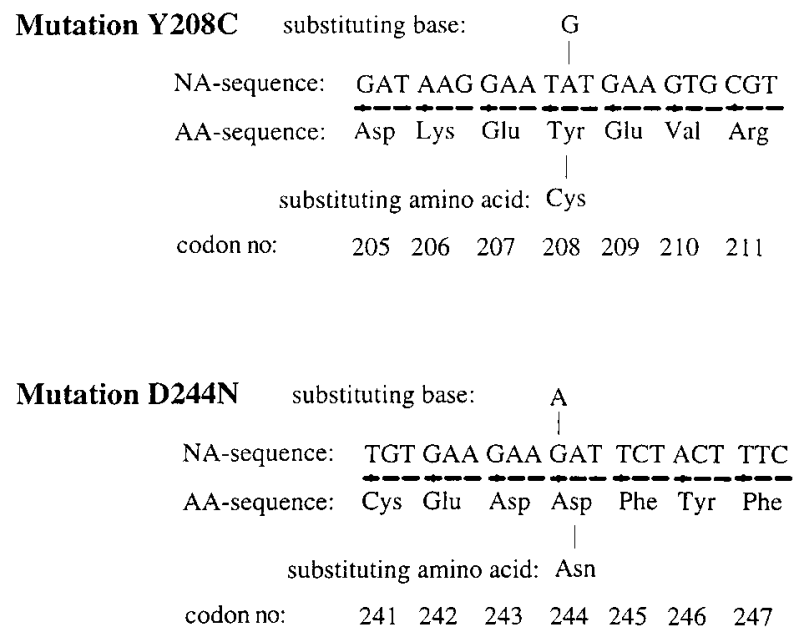

(B)

Human GHR

Rabbit GHR

Rat GHR

Ovine GHR

Chicken GHR
Pos 208

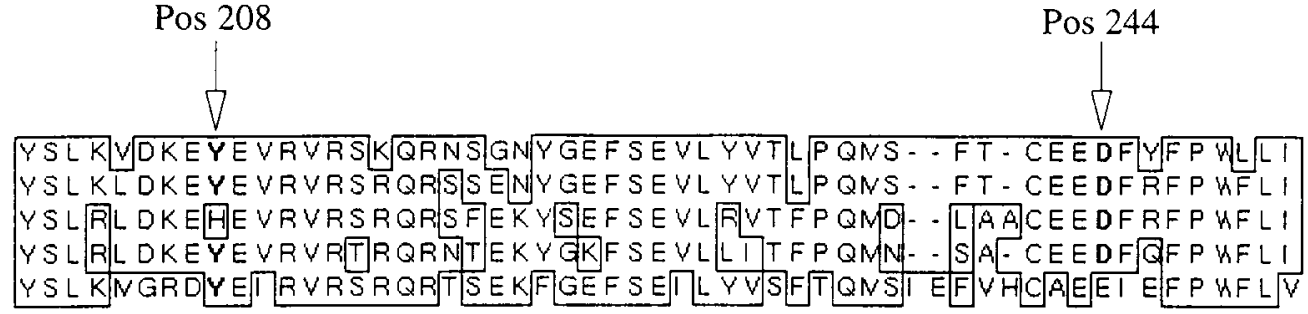

Figure 3 (A) Location of mutations in exon 7 and in $\mathrm{GH}$ receptor amino acid (AA) sequence. NA, nucleic acid sequence. (B) Comparision of $\mathrm{hGH}$ receptor sequences over an area that contains residues 208 and 244 . GH receptor (GHR) sequences from human, rabbit, rat, ovine and chicken were obtained through the gene bank data base.

showed no differences between patients, their parents and controls when banding patterns were compared (data not shown). Sequencing of genomic DNA (exons $2,4,5,6,7)$ revealed that patients were compound heterozygous, carrying two missense mutations in exon 7 of the GH receptor gene (Fig. 3A). Their mother was heterozygous for the first mutation Tyr208Cys while codon 244 was unaffected. Their father was shown to have an unaffected tyrosine codon in position 208, while he was heterozygous for the second mutation, Asp244Asn. Conservation of both tyrosine 208 and aspartic acid 244 has been demonstrated in eight different species (5), with the exception of a histidine in position 208 of rodents (Fig. 3B).

An interpretation of the three-dimensional structure of the soluble $\mathrm{GH}$ receptor in complex with hGH revealed that the naturally occurring Tyr208 fulfils a crucial role in the stabilisation of the C-terminal domain of the receptor by a favourable hydrogen bond via the hydroxyl group to the main chain nitrogen of Lys203. In addition, the side chain of Tyr208 is also within hydrophobic interaction distance with side chains of Tyr178, Leu202 and the aliphatic portions of the side chains of Lys206 Glu180, thus stabilising the hydrophobic core of the C-terminal domain. The Tyr208 to Cys substitution will most likely prevent normal interactions in this structural domain due, to the differences in charge and size of the tyrosine and cysteine side chains, thereby disrupting the native structure in the membrane proximal domain of the extracellular part of the receptor. It is therefore expected that a substitution of Tyr208 to Cys would result in a destabilisation of the protein structure, thus abrogating normal receptor-receptor interactions and preventing efficient signal transduction. Furthermore, it is possible that the unpaired Cys208 residue could be involved in erroneously linked receptors by forming disulphide bridges with a Cys208 residue of a neighbouring receptor or to Cys241. However, in order to be involved in disulphide linking, the cysteine needs, at least to some extent, to be surface exposed, which is less likely if the Cterminal domain keeps its three-dimensional architecture in the mutated receptor. We have not been able to structurally interpret the consequences for the Asp244 to Asn substitution, due to the absence of structural data in this region of the receptor.

\section{Discussion}

There has been no previous record of any Swedish patient who displayed classical physical and biochemical characteristics of LS. In Scandinavia, a Danish patient has previously been reported (17). The Swedish family on whom we focused in this study has no 
Figure 4 (A) Model of the extracellular part of the GH receptor in complex with its ligand (based on co-ordinates from reference 16). The extracellular part of the hGH receptors (hGHbp) are shown by bolder lines and the $\mathrm{hGH}$ ligand by finer lines. Interaction of hGH with its receptor at site 1 is shown to the left and the other ligand interaction part (site 2) is shown to the right of the complex. The square in the right hand receptor part indicates the area where the mutation Y208C is located. It has been enlarged in (B) where the location of Y208 in hGH-BP is shown. A favourable bond of the hydroxyl group of Y208 to K203 is indicated. The close relation to Y178, L202, E180 and K206 is also shown (see also text).

apparent relation to families in which $\mathrm{GH}$ receptor mutations are common. A sensitive method for analysis of genomic DNA sequences allowed us to discriminate between intact and altered $\mathrm{GH}$ receptor alleles using lymphocyte material. Our finding of two unique separate genetic defects implies that there is a low frequency of dysfunctional GH receptor alleles distributed in the Swedish population. The likelihood of identifying additional severe GH receptor gene defects in Scandinavia is however low, considering the lack of more patients and the fact that it seems to be impossible to clinically distinguish heterozygotes carrying a single

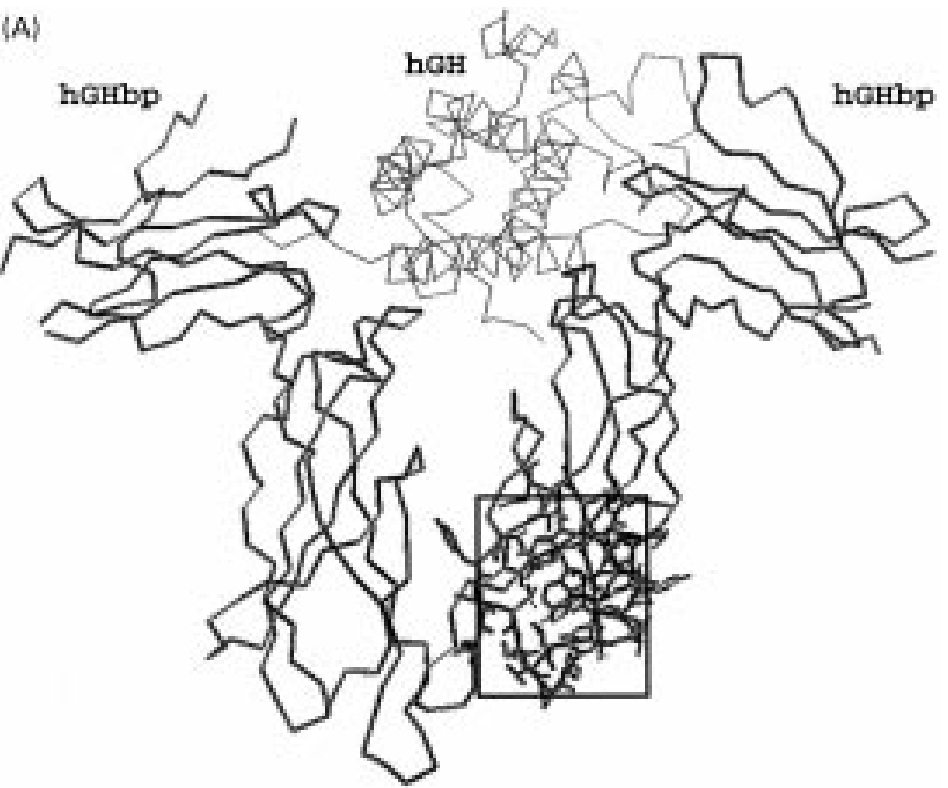

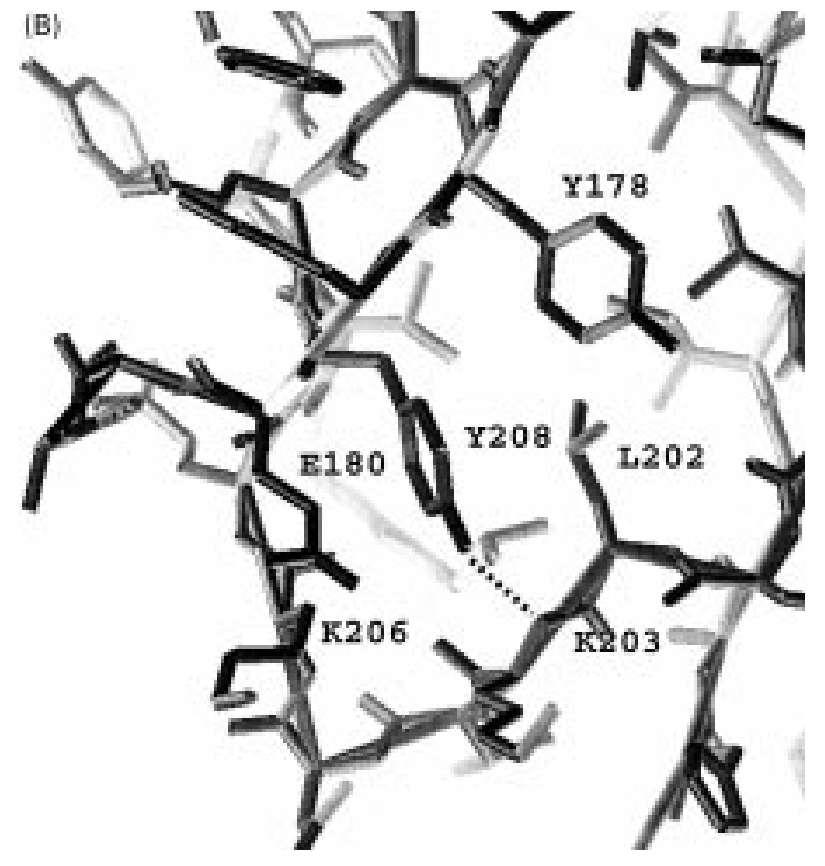

defective $\mathrm{GH}$ receptor allele from intact homozygotes (7, 18). Both parents investigated in this study demonstrate that carrying one defective $\mathrm{GH}$ receptor allele has little or no effect on body growth. Codon 208, which harbours the first mutation identified in this study, encodes a tyrosine residue that is conserved in six species out of eight. In rodents, a histidine residue replaces the action of tyrosine in this position (Fig. 2B). As implied by the GH receptor model (Fig. 4), the side chain of the substituting cysteine in position 208 does not reach the contact points surrounding the 'tyrosine pocket'. This will most likely destabilise the receptor 
structure, thus preventing normal receptor function due to altered conformational and structural properties in the receptor-receptor interface required for normal hormone-induced receptor dimerisation. An additional unpaired cysteine residue will have the potential to form disulphide bridges by interacting with either Cys 208 or Cys241 of a neighbouring receptor, provided that the cysteine side chain is at least partly surface exposed due to local distortions of the three-dimensional structure. In rodents, the His 208 residue most likely performs a similar function to the one seen in the human receptor by Tyr208, although variations in the local structure and interaction patterns will have to be analysed by inspection and analysis of homology models or experimentally determined structures of the corresponding protein complexes.

It is also to be noted that codon 244 spans the borders of exons 7 and 8 in the hGH receptor gene (2), and the identified mutation (A to $\mathrm{G}$ transition) is located in the last coding base of exon 7 . It is a possibility that $\mathrm{GH}$ receptor mRNA splicing could be affected by this mutation, which could then generate a defective $\mathrm{GH}$ receptor.

Several different genetic alterations in the $\mathrm{GH}$ receptor gene have the potential to cause LS (see references 8 and 13 for reviews). The previously identified deletions, splice defects, nonsense and missense mutations all involve the extracellular domain of the receptor, with one exception (19).

In conclusion, we have shown that both of the mutations described in these Swedish patients with LS have the potential to cause a malfunction of the $\mathrm{GH}$ receptor. Obviously the existence of a normal allele prevents the syndrome from appearing. As yet we have not experimentally evaluated the effects of these receptor mutations in terms of, for example, binding or signalling.

\section{Acknowledgements}

The excellent technical assistance of Siwonne Arvidsson is acknowledged. We are grateful to Genentech Inc. for providing access to hGH receptor $\mathrm{cDNAs}$ and Pharmacia \& Upjohn Co. for providing IGF-I for treatment. This work was supported by grants from the Swedish Medical Research Council No. 13X-08556.

\section{References}

1 Laron Z, Pertzelan A \& Mannheimer S. Genetic pituitary dwarfism with high serum concentration of growth hormone: a new inborn error of metabolism? Israeli Journal of Medicine 19662 152-155.

2 Godowski PJ, Leung DW \& Meacham LR. Characterization of the growth hormone receptor gene and demonstration of a partial gene deletion in two patients with Laron-type dwarfism. PNAS $1989868083-8087$.
3 Leung DW, Spencer SA \& Cachianes G. Growth hormone receptor and serum binding protein: purification, cloning and expression. Nature $1987330537-543$.

4 Kelly PA, Djiane J, Postel-Vinay MC \& Edery M. The prolactin/ growth hormone receptor family. Endocrine Reviews 199112 235-251.

5 Bazan FJ. A novel family of growth factor receptors: a common binding domain in the growth hormone, prolactin, erythropoetin and IL- 6 receptors, and the p75 IL- 2 receptor $\beta$-chain. Biochemical and Biophysical Research Communications 1989164 788-795.

6 Baumann G. Growth hormone binding proteins. Proceedings of the Society for Experimental Biology and Medicine 1993202 392-400.

7 Laron Z, Klinger B, Erster B \& Silbergeld A. Serum GH binding protein activities identifies the heterozygous carriers for Laron type dwarfism. Acta Endocrinologica 1989121 603-608.

8 Clayton PE, Freeth JS, Whatmore AJ, Ayling RM, Norman MR \& Silva CM. Signal transduction defects in growth hormone insensitivity. Acta Paediatrica Scandinavica 199988 174-178.

9 Boguszewski CL, Carlsson B \& Carlsson LM. Mechanisms of growth failure in non-growth-hormone deficient children of short stature. Hormone Research 199748 19-22.

10 Wood TJ, Haldosén L-A, Sliva D, Sundström M \& Norstedt G. Stimulation of kinase cascades by growth hormone; a paradigm for cytokine signalling. Progress in Nucleic Acid Research and Molecular Biology 199757 73-94.

11 Laron Z, Pertzelan A, Karp M, Kowadlo-Silbergeld A \& Daughaday WH. Administration of growth hormone to patients with familial dwarfism with high plasma immunoreactive growth hormone: measurement of sulfation factor, metabolic and linear growth responses. Journal of Clinical Endocrinology and Metabolism $197133332-342$.

12 Daughaday WH \& Rotwein P. Insulin-like growth factors I and II. Peptide, messenger ribonucleic acid and gene structures, serum and tissue concentrations. Endocrine Reviews 198910 68-91.

13 Rosenfeld RG, Rosenbloom AL \& Guevaraaguirre J. Growth hormone $(\mathrm{GH})$ insensitivity due to primary $\mathrm{GH}$ receptor deficiency. Endocrine Reviews 19943 369-390.

14 Amselem S, Sobrier ML, Dastot F, Duquesnoy P, Duriez B \& Gossens M. Molecular basis of inherited growth hormone resistance in childhood. Baillieres Clinical Endocrinology and Metabolism $199610353-369$.

15 Ranke MB. Treatment of growth hormone insensitivity syndrome (GHIS) with insulin-like growth factor (IGF-I). Baillieres Clinical Endocrinology and Metabolism 199610 401-410.

16 Sundström M, Milligan D, Rödin J, Giebel L, Lundquist T \& Norstedt G. The crystal structure of an antagonist mutant of human growth hormone in complex with its receptor at $2.9 \AA$ resolution - a comparision with the native hormone complex at $2.5 \AA$ A. Journal of Biological Chemistry 199627132 197-201.

17 Kastrup KW, Andersen H \& Hanssen AF. Increased immunoreactive plasma and urinary growth hormone in growth retardation with defective generation of somatomedin a (Laron's Syndrome). Acta Paediatrica Scandinavica 197564 613-618.

18 Rosenbloom AL, Guevara-Aguirre J, Rosenfeld RG \& Fielder PJ. Is there heterozygote expression of growth hormone receptor deficiency? Acta Paediatrica Scandinavica 199483 125-127.

19 Kou K, Lajara R \& Rotwein P. Amino acid substitutions in the intracellular part of the growth hormone receptor in a patient with the Laron syndrome. Journal of Clinical Endocrinology and Metabolism 19931 54-59.

Received 17 March 1999

Accepted 8 March 2000 